\title{
PENERAPAN MODEL PROBLEM BASED LEARNING DAN MODEL PROJECT BASED LEARNING TERHADAP HASIL BELAJAR SISWA PADA MATERI GETARAN DAN GELOMBANG
}

\author{
Effendi $^{1}$, Melvi Sugiarti ${ }^{2}$, Wahid Gunarto ${ }^{3}$ \\ Sekolah Tinggi Keguruan dan Ilmu Pendidikan (STKIP) Nurul Huda \\ Sukaraja Buay Madang OKU Timur ${ }^{1,2,3}$ \\ effendi@stkipnurulhuda.ac.id ${ }^{1}$
}

Submit, 29-04-2019 Accepted,30-06-2019 Publish, 30-06-2019

\begin{abstract}
The purpose of this study is to find out whether there are significant differences in learning outcomes between students whose learning uses PBL learning models with PjBL learning models in the Vibration and Wave material in Class VIII Belitang Madang Raya 3 Middle School Learning Year 2017/2018. The type of research used in this study is quantitative research methods. The population in this study were class VIII students in the Belitang State Junior High School 3 in Madang Raya consisting of 6 classes. The sampling technique in this study was carried out in a random manner through drawing existing classes. Data collection techniques to find out the learning outcomes of students using tests, and testing hypotheses using the z-test. Based on student learning outcomes after the test is obtained the average value of the experimental class I is 81.88 and the average value of the experimental class II is 73.2. There are significant differences in learning outcomes between students whose learning uses the PBL learning model with the PjBL learning model in the material of Vibration and Waves in Class VIII of the State Middle School 3 Belitang Madang Raya Learning Year 2017/2018. This can be seen from the value of Zhit $=39.3$ not located between -1.96 and 1.96, so that HO is rejected and Ha is accepted.
\end{abstract}

Keywords: Problem Based Learning, Project Based Learning, Student Learning Outcomes.

Abstrak. tujuan penelitian ini untuk mengetahui apakah terdapat perbedaan yang signifikan hasil belajar antara peserta didik yang pembelajarannya menggunakan model pembelajaran PBL dengan model pembelajaran PjBL pada materi Getaran dan Gelombang di Kelas VIII SMP Negeri 3 Belitang Madang Raya Tahun Pembelajaran 2017/2018. Jenis penelitian yang digunakan dalam penelitian ini adalah metode penelitian kuantitatif. Populasi dalam penelitian ini adalah peserta didik kelas VIIIdi SMPNegeri3 Belitang Madang Raya yang terdiri dari 6 kelas. Teknik pengambilan sampel dalam penelitian ini dilakukan dengan cara acak melalui pengundian kelas yang sudah ada. Teknik pengumpulan data untuk mengetahui hasil belajar peserta didik menggunakan tes, dan pengujian hipotesisnya menggunakan uji-z.Berdasarkan hasil belajar peserta didik setelah diadakan tes diperoleh nilai rata- rata kelas eksperimen I adalah 81,88 dan nilai rata-rata kelas kelas eksperimen II adalah 73,2. Terdapat perbedaan yang signifikan hasil belajar antara peserta didik yang pembelajarannya menggunakan model pembelajaran PBL dengan model pembelajaran PjBL pada materi Getaran dan Gelombang di Kelas VIII SMP Negeri 3 Belitang Madang Raya Tahun Pembelajaran 2017/2018. Hal ini dapat dilihat dari nilai $Z_{\text {hit }}=39,3$ tidak terletak antara $-1,96$ dan 1,96, sehingga $H_{0}$ di tolak dan $H_{a}$ diterima.

Kata Kunci:Problem Based Learning, Project Based Learning, Hasil Belajar Peserta Didik.

\section{PENDAHULUAN}

Sesuai tujuan pendidikan nasional yang telah diterapkan pada Undang-undang RI No 20 tahun 2003 tentang sistem pendidikan nasional yaitu: "Pendidikan nasional bertujuan mencerdaskan kehidupan bangsa dan mengembangkan manusia Indonesia seutuhnya yaitu manusia yang beriman dan bertaqwa kepada Tuhan Yang Maha Esa dan berbudi pekerti luhur, memiliki pengetahuan dan ketrampilan, kesehatan jasmani dan rohani, kepribadian yang mantap dan mandiri, serta rasa bertanggung jawab kemasyarakatan dan kebangsaan". Proses pendidikan 
merupakan suatu sistem yang terdiri dari input, proses, dan output. Input merupakan peserta didik yang akan melaksanakan aktivitas belajar. Proses merupakan kegiatan dari pembelajaran, sedangkan output merupakan hasil dari proses yang dilaksanakan. Salah satu cara untuk mewujudkan tujuan daripendidikan adalah adanya proses kegiatan pembelajaran. Kegiatan pembelajaran adalah suatu proses dalam rangka mencapai tujuan Pendidikan Nasional.

Menurut Abdullah (2017) model pembelajaran Problem Based Learning $(P B L)$ merupakan model pembelajaran yang penyampaiannya dilakukan dengan menyajikan suatu permasalahan, mengajukan pertanyaan, menfasilitasi penyelidikan, dan membuka dialog serta memecahkan masalah, menerapkan beberapa konsep dan prinsip yang secara stimulasi dipelajari dan tercangkup dalam kurikulum mata pelajaran. Prinsip PBL itu sendiri adalah peserta didik tidak hanya memperoleh pengetahuan tetapi juga mereka tahu bagaimana menerapkan pengetahuan ini dalam situasi nyata. Beberapa karakteristik dari model pembelajaran PBL maka dapat dipahami bahwa karakteristik dari PBL antara lain permasalahan menjadi titik awal dalam pembelajaran, pembelajarannya menekankan pada pembelajaran secara berkelompok, dan adanya evaluasi dan review pada akhir dari proses pembelajaran.

Daryanto (2014) menjelaskan bahwa model pembelajaran PjBL (Project Based Learning) adalah model pembelajaran yang menggunakan projek/kegiatan sebagai media. Peserta didik melakukan eksplorasi, penilaian, interprestasi, sintesis, dan informasi untuk menghasilkan berbagai bentuk hasil belajar.Pembelajaran ini menggunakan masalah sebagai langkah awal dalam menggumpulkan pengetahuan baru berdasarkan pengalamannya dalam beraktivitas secara nyata. Karakteristik dari model pembelajaran $\mathrm{PjBL}$ antara lain adanya permasalahan atau tantangan yang diajukan ke peserta didik, pembuatan proyek menjadi pusat dalam pembelajaran, dan guru hanya sebagai fasilitator karena peserta didik tuntut untuk berinvestigasi secara mandiri.

\section{LANDASAN TEORI \\ Tinjuan tentang belajar}

Definisi dari belajar adalah kegiatan berproses dan merupakan unsur yang sangat fundamental dalam setiap jenjang pendidikan. Dalam keseluruhan proses pendidikan, kegiatan belajar merupakan kegiatan yang paling pokok dan penting dalam keseluruhan proses pendidikan. Menurut Sardiman (2011) Belajar berarti serangkaian kegiatan jiwa raga, psiko fisik untuk menuju ke perkembangan pribadi manusia seutuhnya, yang berarti menyangkut aspek ranah kognitif, afektif, dan psikomotorik.Belajar merupakan tindakan dan perilaku peserta didik yang kompleks. Sebagai tindakan maka belajar hanya dialami oleh peserta didik sendiri dan akan menjadi penentu terjadinya atau tidak terjadinya proses belajar.Kegiatan belajar tersebut ada yang dilakukan di sekolah, di rumah, dan di tempat lain seperti di museum, di laboratorium, di hutan dan dimana saja. Menurut Gagne (dalam Rusman, 2014) belajar merupakan sebuah sistem yang didalamnya terdapat berbagai unsur yang saling terkait sehingga menghasilkan perubahan tingkah perilaku. Lebih lanjut, Abdillah 2002 (dalam Anurrahman, 2010) menyimpulkan bahwa "Belajar adalah suatu usaha sadar yang dilakukan oleh individu dalam perubahan tingkah laku baik melalui latihan dan pengalaman yang menyangkut aspek-aspek kognitif, afektif, dan psikomotorik untuk memperoleh tujuan tertentu." 
Berdasarkan pengertian belajar dari beberapa pendapat di atas, dapat dimaknai bahwa belajar yaitu perubahan tingkah laku pada individu-individu yang belajar. Perubahan itu tidak hanya berkaitan dengan penambahan ilmu pengetahuan, tetapi juga berbentuk kecakapan, keterampilan, sikap, pengertian, harga diri, minat, watak, penyesuaian diri. Oleh karena itu dapat dikatakan bahwa belajar itu sebagai rangkaian kegiatan jiwa raga yang menuju perkembangan pribadi manusia seutuhnya.

\section{Tinjauan tentang hasil belajar}

Hasil belajar adalah angka yang diperoleh peserta didik yang telah berhasil menuntaskan konsep-konsep mata pelajaran sesuai dengan Kriteria Ketuntasan Minimal (KKM) yang ditetapkan sesuai dengan kurikulum yang berlaku. Begitu juga hasil belajar dapat diartikan sebagai perubahan tingkah laku yang tetap sebagai hasil proses pembelajaran. Hasil belajar dapat diklasifikasikan menjadi tiga ranah, yaitu ranah kognitif, afektif, dan psikomotorik.

Berkaitan dengan tiga kategori ranah belajar tersebut dalam teori Taksonomi Bloom sebagai dikutip Ansori (2008) dijelaskan sebagai berikut: 1) ranah kognitif berkenaan dengan hasil belajar intelektual yang terdiri dari 6 aspek yaitu pengetahuan, pemahaman, penerapan, analisis, sintesis dan penilaian, 2) ranah afektif berkenaan dengan sikap dan nilai. Ranah afektif meliputi dengan lima jenjang kemampuan yaitu menerima, menjawab atau reaksi, menilai, organisasi dan karakterisasi dengan suatu nilai atau kompleks nilai, 3) ranah psikomotor miliki keterampilan motorik, manipulasi benda-benda, koordinasi, neoromuscular, atau menghubungkan dengan mengamati.
Salah satu penilaian hasil belajar dalam aspek kognitif (penguasaan konsep). Aspek kognitif yang digunakan adalah taksonomi Bloom baru versi krathwolh (dalam Rusman, 2014) yang terdiri dari enam level, yaitu pengetahuan atau ingatan (C1), pemahaman (C2), penerapan (C3), analisis (C4), sintesis (C5), dan evaluasi (C6). Revisi Krathwolh sering digunakan dalam merumuskan tujuan belajar yang sering dikenal dengan istilah C1 sampai C6.

\section{Pengertian model pembelajaran}

Model pembelajaran menurut Weil (dalam Rusman, 2014) adalah suatu rencana atau pola yang dapat digunakan untuk membentuk kurikulum, merancang bahan-bahan pembelajaran, dan membimbing pembelajaran dikelas. Beberapa model-model pembelajaran antara lain model pembelajaran koperatif, kontekstual, realistik, pembelajaran langsung, pembelajaran berbasis masalah, dan lain sebagainya. Berdasarkan masalah yang terjadi pada proses pembelajaran, maka peneliti akan menggunakan salah satu model pembelajaran yang diharapkan efektif untuk dilakukan dalam kegiatan pembelajaran adalah model pembelajaran berbasis masalah yaitu model pembelajaran PBL (Problem Based Learning) dan PjBL (Project Based Learning).

\section{Model pembelajaran Problem Based Learning}

PBL merupakan penggunaan berbagai macam kecerdasan yang diperlukan untuk melakukan konfrontasi terhadap tentangan dunia maya, kemampuan untuk menghadapi segala sesuatu yang baru dari kompleksitas yang ada, menurut Tan (dalam Rusman, 2014). Sedangkan menurut Daryanto (2014) menyatakan bahwa pembelajaran berbasis masalah atau PBL merupakan 
sebuah pendekatan pembelajaran yang menyajikan masalah konstektual sehingga merangsang peserta didik untuk belajar. Pembelajran berbasis masalah merupakan suatu model pembelajaran yang menantangn peserta didik untuk "belajar bagaimana belajar", bekerja secara berkelompok untuk mencari solusi dari permasalahan dunia nyata masalah yangn diberikan digunakan untuk mengikat peserta didik pada rasa ingin tahu pada pembelajaran yang dimaksud. Masalah diberikan kepada peserta didik, sebelum peserta didik mempelajari konsep atau materi yang berkenaan dengan masalah yang harus dipecahkan.

Dilihat dari aspek psikologi strategi pembelajaran berbasis masalah didasarkan pada aspek psikologi kognitif bahwa belajar adalah proses perubahan tingkah laku karena adanya pengalaman, bukan menghafal fakta, tetapi proses interaksi secara sadar antara individu dengan lingkungannya, sehingga malalui proses ini maka peserta didik akan berkembang secara utuh (Warsono, 2016)

Proses pembelajaran PBL terdiri dari lima tahapan (sintaks) utama (Warsono, 2016) yang dijabarkan pada table1 berikut:

Tabel 1 Sintaks Pelaksanaan Pembelajaran PBL

\begin{tabular}{|c|c|}
\hline $\begin{array}{c}\text { Langkah-langkah } \\
\text { Pokok }\end{array}$ & Kegiatan Guru \\
\hline $\begin{array}{l}\text { Tahap } 1 \\
\text { Memberikan orientasi } \\
\text { tentang permasalahan } \\
\text { pada peserta didik }\end{array}$ & $\begin{array}{l}\text { Menjelakan tujuan } \\
\text { pembelajaran, } \\
\text { menjelaskan } \\
\text { kebutuhan-kebutuhan } \\
\text { yang diperlukan, dan } \\
\text { motivasi peserta didik } \\
\text { agar terlibat pada } \\
\text { kegiatan pemecahan } \\
\text { masalah }\end{array}$ \\
\hline $\begin{array}{l}\text { Tahap } 2 \\
\text { Mengorganisasi } \\
\text { peserta didik untuk } \\
\text { meneliti }\end{array}$ & $\begin{array}{l}\text { Membantu peserta } \\
\text { didik menentukan dan } \\
\text { mengatur tugas belajar } \\
\text { yang berkaitan dengan } \\
\text { masalah yang } \\
\text { diangkat }\end{array}$ \\
\hline
\end{tabular}

\begin{tabular}{|c|c|}
\hline $\begin{array}{l}\text { Tahap } 3 \\
\text { Membimbing } \\
\text { penyelidikan peserta } \\
\text { didik secara mandiri } \\
\text { maupun kelompok }\end{array}$ & $\begin{array}{l}\text { Mendorong peserta } \\
\text { didik untuk } \\
\text { mengumpulkan } \\
\text { informasi yang sesuai, } \\
\text { melaksanakan } \\
\text { eksperimen untuk } \\
\text { mendapatkan } \\
\text { penjelasan dan } \\
\text { pemecahan masalah }\end{array}$ \\
\hline $\begin{array}{l}\text { Tahap } 4 \\
\text { Mengembangkan dan } \\
\text { menyajikan hasil } \\
\text { karya }\end{array}$ & $\begin{array}{l}\text { Membantu peserta } \\
\text { didik dalam } \\
\text { merencanakan dan } \\
\text { menyiapkan karya } \\
\text { yang sesuai, seperti } \\
\text { laporan, video, model; } \\
\text { dan membantu peserta } \\
\text { didik dalam berbagai } \\
\text { tugas dengan } \\
\text { temannya untuk } \\
\text { menyampaikan } \\
\text { kepada orang lain }\end{array}$ \\
\hline $\begin{array}{l}\text { Tahap 5 } \\
\text { Menganalisis dan } \\
\text { mengevaluasi proses } \\
\text { pemecahan masalah }\end{array}$ & $\begin{array}{l}\text { Membantu peserta } \\
\text { didik melakukan } \\
\text { refleksi dan } \\
\text { mengadakan evaluasi } \\
\text { terhadap penyelidikan } \\
\text { dan proses-proses } \\
\text { belajar yang mereka } \\
\text { lakukan }\end{array}$ \\
\hline
\end{tabular}

Model pembelejaran Project Based Learning Daryanto (2014) menjelaskan bahwa model pembelajaran $\mathrm{PjBL}$ adalah model pembelajaran yang menggunakan projek/kegiatan sebagai media. Peserta didik melakukan eksplorasi, penilaian, interprestasi, sintesis, dan informasi untuk menghasilkan berbagai bentuk hasil belajar. Menurut Warsono (2016) PjBL didefinisikan sebagai suatu pengajaran yang mencoba mengaitkan antara teknologi dengan masalah kehidupan sehari-hari yang akrab dengan siswa, atau dengan suatu proyek Sekolah. Pembelajaran ini menggunakan masalah sebagai langkah awal dalam menggumpulkan pengetahuan baru berdasarkan pengalamannya dalam beraktivitas secara nyata.

$$
\text { Menurut Daryanto }
$$
beberapa karekteristik dari $\mathrm{PjBL}$ adalah: 1) peserta didik membuat keputusan tentang sebuah kerangka kerja, 2) 
adanya permasalahan atau tantangan yang diajukan kepada peserta didik, 3) peserta didik mendesain proses untuk menentukan solusi atas permasalahan atau tantangan yang diajukan, 4) peserta didik secara kolaboratif bertanggungjwab untuk mengakses dan mengolah informasi untuk memecahkan permasalahan, 5) proses evaluasi dijalankan secara kontinyu, 6) peserta didik secara berkala melakukan refleksi atas aktivitas yang sudah dijalankan, 7) produk akhir aktivitas belajar akan dievaluasi secara kualitatif, 8) situasi pembelajaran sangat toleran terhadap kesalahan dan perubahan.

$$
\text { Adapun langkah-langkah }
$$

pembelajaran $\mathrm{PjBL}$ sebagaimana tabel berikut:

Tabel 2 Sintaks Pembelajaran PjBL

\begin{tabular}{|c|c|}
\hline $\begin{array}{c}\text { Tahapan } \\
\text { Pembelajaran }\end{array}$ & Aktivitas Pembelajaran \\
\hline $\begin{array}{l}\text { Penentuan } \\
\text { proyek }\end{array}$ & $\begin{array}{l}\text { Peserta didik menentukan } \\
\text { tema atau topik proyek } \\
\text { berdasarkan tugas proyek } \\
\text { yang diberikan oleh guru, } \\
\text { diberi kesempatan untuk } \\
\text { memilih atau menentukan } \\
\text { proyek yang dikerjakan } \\
\text { secara kelompok atau } \\
\text { mandiri dengan tidak } \\
\text { menyimpang dari tugas } \\
\text { yang diberikan guru. }\end{array}$ \\
\hline $\begin{array}{c}\text { Perencanaan } \\
\text { langkah-langkah } \\
\text { penyelesaian } \\
\text { kelompok }\end{array}$ & $\begin{array}{l}\text { Peserta didik merancang } \\
\text { tahapan kegiatan } \\
\text { penyelesaian proyek dari } \\
\text { awal sampai akhir beserta } \\
\text { pengelolaannya. }\end{array}$ \\
\hline $\begin{array}{l}\text { Penyusunan } \\
\text { jadwal }\end{array}$ & $\begin{array}{lr}\text { Perencanaan dan } & \text { waktu } \\
\text { proyek dilakukan dibawah } \\
\text { pendampingan. Pendidik } \\
\text { menjadwalkan semua } \\
\text { kegiatan yang telah } \\
\text { dirancannya, beberapa lama } \\
\text { proyek tersebut harus } \\
\text { diselesaikan tahap demi } \\
\text { tahap. }\end{array}$ \\
\hline $\begin{array}{l}\text { Penyelesaian } \\
\text { proyek dengan } \\
\text { fasilitas dan } \\
\text { monitoring guru }\end{array}$ & $\begin{array}{l}\text { Pengimplementasian } \\
\text { perancangan proyek yang } \\
\text { telah dibuat, aktivitas yang } \\
\text { dapat dilakukan dalam } \\
\text { kegiatan proyek adalah: a) } \\
\text { membaca, b) meneliti, c) } \\
\text { observasi, d) interview, e) } \\
\text { merekam, f) bekarya seni, }\end{array}$ \\
\hline
\end{tabular}

\begin{tabular}{cl}
\hline & $\begin{array}{l}\text { g) mengunjungi obyek } \\
\text { proyek, atau h) akses } \\
\text { internet. }\end{array}$ \\
\hline $\begin{array}{c}\text { Menyusun } \\
\text { laporan dan }\end{array}$ & $\begin{array}{l}\text { Menyusun hasil proyek } \\
\text { dalam bentuk produk, baik }\end{array}$ \\
persentasi dan & $\begin{array}{l}\text { itu berupa karya tulis, karya } \\
\text { publikasi }\end{array}$ \\
& $\begin{array}{l}\text { seni, atau karya teknologi } \\
\text { atau prakarya yang } \\
\text { dipublikasikan. }\end{array}$ \\
\hline Evaluasi proses & $\begin{array}{l}\text { Evaluasi proses dan hasil } \\
\text { proyek dengan melakukan }\end{array}$ \\
dan hasil proyek & $\begin{array}{l}\text { refleksi terhadap aktivitas } \\
\text { dan hasil tugas proyek. }\end{array}$ \\
\hline
\end{tabular}

\section{METODE PENELITIAN}

\section{Waktu dan Tempat Penelitian}

Waktu penelitian merupakan waktu dilaksanakannya suatu penelitian oleh seorang peneliti terhadap objek penelitian. Waktu penelitian yang akan ditentukanoleh peneliti direncanakan pada semester genapTahun Pembelajaran 2017/2018 dan tempat penelitian dilaksanakan di kelas VIII SMP Negeri 3 Belitang Madang Raya.

\section{Jenis Penelitian}

Jenis penelitian yang digunakan dalam penelitian ini adalah metode penelitian kuantitatif. Desain penelitian yang digunakan terdapat pada tabel 3

\begin{tabular}{lcc}
\multicolumn{3}{c}{ Tabel 3 Desain Penelitian } \\
\hline Kelas & $\mathrm{X}_{1}$ & $\mathrm{O}_{2}$ \\
Eksperimen 1 & & \\
\hline Kelas & $\mathrm{X}_{2}$ & $\mathrm{O}_{2}$ \\
Eksperimen 2 & & \\
\hline
\end{tabular}

Berdasarkan tabel 3 pada kelas eksperimen I diberikan perlakuan yaitu dengan menggunakan model pembelajaran PBL dan pada kelas eksperimen II menggunakan model pembelajaran $\mathrm{PjBL}$, kemudian peneliti sama-sama memberikan test pada akhir pembelajaran atau posttest pada kedua kelas tersebut.

\section{Variabel penelitian}

Arikunto (2010) mengatakan variabel penelitian adalah gejala yang 
bervariasi dalam penelitian. Variabel penelitian dapat dibedakan menjadi dua yaitu

Variable bebas

Variabel independen (bebas) adalah variabel yang menjadi sebab terjadinya (terpengaruhnya) variabel dependen (terikat) (Sugiyono, 2010). Dalam penelitian ini variabel bebasnya $(X)$ adalah model pembelajaran. Dalam hal ini model pembelajaran yang digunakan dalam penelitian yang digunakan adalah Model Pembelajaran PBL dan Model Pembelajaran PjBL.

Variableterikat.

Variabel dependen (terikat) merupakan variabel yang nilainya dipengaruhi oleh variabel independen atau disebut juga variabel akibat (Arikunto, 2010). Variabel terikat $(Y)$ dalam penelitian ini adalah hasil belajar Fisika peserta didik pada Materi Getaran dan Gelombang di kelas VIII SMP Negeri 3 Belitang Madang Raya Tahun Pembelajaran 2017/2018.

\section{HASIL PENELITIAN \\ Uji Validitas Instrumen}

Pengujian validitas instrumen dilakukan dengan tujuan untuk mengetahui apakah instrumen yang digunakan dalam penelitian telah valid. Untuk mengetahui validitas instrumen yang akan digunakan dalam penelitian ini menggunakan rumus korelasi product moment. Adapun hasil pengujian validitas terdapat pada tabel 4 .

Tabel 4 Hasil Uji Validitas Butir Soal

\begin{tabular}{cccc}
\hline No & $\begin{array}{c}\text { Koefisien } \\
\text { Korelasi } \\
\mathbf{r}_{\text {hitung }}\end{array}$ & $\begin{array}{c}\text { Harga } \\
\mathbf{r}_{\text {tabel }}\end{array}$ & Kriteria \\
\hline 1 & 0,454 & 0,361 & Valid \\
\hline 2 & 0,547 & 0,361 & Valid \\
\hline 3 & 0,104 & 0,361 & Invalid \\
\hline 4 & 0,386 & 0,361 & Valid \\
\hline 5 & 0,015 & 0,361 & Invalid \\
\hline 6 & 0,143 & 0,361 & Invalid \\
\hline 7 & 0,489 & 0,361 & Valid \\
\hline
\end{tabular}

\begin{tabular}{cccc}
\hline 8 & 0,404 & 0,361 & Valid \\
\hline 9 & 0,532 & 0,361 & Valid \\
\hline 10 & 0,402 & 0,361 & Valid \\
\hline 11 & 0,435 & 0,361 & Valid \\
\hline 12 & 0,500 & 0,361 & Valid \\
\hline 13 & 0,409 & 0,361 & Valid \\
\hline 14 & 0,450 & 0,361 & Valid \\
\hline 15 & 0,011 & 0,361 & Invalid \\
\hline 16 & 0,472 & 0,361 & Valid \\
\hline 17 & 0,370 & 0,361 & Valid \\
\hline 18 & 0,850 & 0,361 & Valid \\
\hline 19 & 0,370 & 0,361 & Valid \\
\hline 20 & 0,529 & 0,361 & Valid \\
\hline 21 & 0,435 & 0,361 & Valid \\
\hline 22 & 0,402 & 0,361 & Valid \\
\hline 23 & 0,610 & 0,361 & Valid \\
\hline 24 & 0,546 & 0,361 & Valid \\
\hline 25 & 0,452 & 0,361 & Valid \\
\hline
\end{tabular}

Berdasarkan tabel4hasil perhitungan uji validitas instrumen diatas menunjukkan dari 25 nomor soal yang diujikan terdapat 4soal yang tidak valid yaitu soal nomor 3, 5, 6, dan 15 karena nilai $r_{\text {hitung }}$ kurang dari $r_{\text {tabel }}$. Oleh karena itu, berdasarkan tingkat validitas terdapat 21 soal valid, sedangkan 4 soal yang tidak valid.

\section{Uji Reliabilitas Instrumen}

Reliabel artinya dapat dipercaya, jadi dapat diandalkan.Pengujian Reliabilitas instrumen soal menggunakan persamaan KR-20. Berdasarkan hasil perhitungan uji reliabilitas instrumen harga koefisien reliabilitas diperoleh $\left(r_{11}\right)=0,78$ lebih besar dari pada 0,70 dengan demikian dapat dinyatakan bahwa instrumen yang akan digunakan dalam penelitian ini adalah reliabel maka instrumen penelitian tersebut dapat digunakan dalam pengumpulan data..

\section{Uji Taraf Kesukaran Instrumen}

Hasil uji coba terhadap 30 siswa kelas VIII SMP Negeri 5 Madang Suku I perolehan skor tertinggi 84 dan skor terendah 20.

Tabel 5 Hasil Taraf Kesukaran Instrumen 


\begin{tabular}{|c|c|c|}
\hline No & $\begin{array}{c}\text { Taraf } \\
\text { Kesukaran }\end{array}$ & $\begin{array}{c}\text { Keterangan } \\
\text { Kriteria }\end{array}$ \\
\hline 1 & 0,9 & Soal Mudah \\
\hline 2 & 0,6 & Soal Sedang \\
\hline 3 & 0,3 & Soal Sukar \\
\hline 4 & 0,47 & Soal Sedang \\
\hline 5 & 0,23 & Soal Sukar \\
\hline 6 & 0,43 & Soal Sedang \\
\hline 7 & 0,73 & Soal Mudah \\
\hline 8 & 0,73 & Soal Mudah \\
\hline 9 & 0,7 & Soal Sedang \\
\hline 10 & 0,7 & Soal Sedang \\
\hline 11 & 0,7 & Soal Sedang \\
\hline 12 & 0,7 & Soal Sedang \\
\hline 13 & 0,27 & Soal Sukar \\
\hline 14 & 0,67 & Soal Sedang \\
\hline 15 & 0,2 & Soal Sukar \\
\hline 16 & 0,73 & Soal Mudah \\
\hline 17 & 0,67 & Soal Sedang \\
\hline 18 & 0,2 & Soal Sukar \\
\hline 19 & 0,67 & Soal Sedang \\
\hline 20 & 0,63 & Soal Sedang \\
\hline 21 & 0,83 & Soal Mudah \\
\hline 22 & 0,7 & Soal Sedang \\
\hline 23 & 0,67 & Soal Sedang \\
\hline 24 & 0,67 & Soal Sedang \\
\hline 25 & 0,63 & Soal Sedang \\
\hline
\end{tabular}

Berdasarkan tabel 4tersebut dapat dinyatakan bahwa terdapat 5 soal dengan kriteria mudah, 15 soal dengan kriteria sedang, dan 5 soal dengan kriteria sulit.

Persentase soal mudah $=$

$\frac{5}{20} \times 100 \%=50 \%$

Persentase soal sedang $=$ $\frac{15}{20} \times 100 \%=75 \%$

Persentase soal sulit = $\frac{5}{20} \times 100 \%=50 \%$

\section{Analisis Daya Pembeda Instrumen}

Daya pembeda instrumen adalah kemampuan suatu instrumen untuk membedakan antara peserta didik yang pandai (berkemampuan yang tinggi) dengan peserta didik yang berkemampuan rendah (Arikunto, 2010).

Tabel 6 Hasil Uji Daya Pembeda Instrumen

\begin{tabular}{cllc}
\hline No & $\begin{array}{c}\text { Kriteria } \\
\text { Daya } \\
\text { Pembeda } \\
\text { Soal }\end{array}$ & $\begin{array}{c}\text { Nomor Butir } \\
\text { Soal }\end{array}$ & $\begin{array}{c}\text { Jumlah } \\
\text { Soal }\end{array}$ \\
\hline 1 & Baik Sekali & - & 0 \\
\hline 2 & Baik & $\begin{array}{l}2,4,7,8,9, \\
12,14,16,20, \\
23, \text { dan } 24\end{array}$ & 11 \\
\hline \multirow{3}{*}{ Cukup } & $\begin{array}{l}1,3,10,11, \\
17,19,21,22, \\
\text { dan } 25\end{array}$ & 9 \\
\hline 4 & Jelek & 6 dan 15 & 2 \\
\hline 5 & $\begin{array}{l}\text { Sangat } \\
\text { Jelek }\end{array}$ & 5,13, dan 18 & 3 \\
\hline \multicolumn{5}{c}{ Jumlah } \\
\hline
\end{tabular}

Berdasarkan tabel 6 dapat diketahui bahwa terdapat 11 soal dengan daya pembeda baik, 9 soal cukup, 2 soal jelek dan 3 soal sangat jelek. Soal yang jelek dan yang sangat jelek tidak digunakan dalam penelitian ini. Sehingga dari 25 soal yang telah diujikan, ada 20 soal yang dapat digunakan dalam penelitian.

\section{Analisis Data Hasil Penelitian}

Data hasil penelitian diperoleh setelah penelitian dilaksanakan kemudian dilanjutkan pengumpulan data hasil penelitian. Pengumpulan data dalam penelitian ini dilakukan dengan cara pemberian soal tes kepada siswa setelah siswa menerima perlakuan dalam kegiatan pembelajarannya. Tes dilakukan pada kelas eksperimen I dengan menggunakan model pembelajaran PBL dan kelas eksperimen II dengan menggunakan model pembelajaran PjBL yang dilakukan pada akhir pertemuan berupa postest. Ada pun rangkuman skor tes hasil belajar Fisika siswa berdasarkan analisis data di atas dapat dilihat pada tabel7. 
Tabel 7 Rangkuman Nilai Tes Hasil Belajar Kognitif Siswa

\begin{tabular}{cccccc}
\hline & & & & Nila \\
$\mathrm{N}$ & Kelas & $\begin{array}{c}\text { Nilai } \\
\text { Tertin } \\
\text { ggi }\end{array}$ & $\begin{array}{c}\text { Nilai } \\
\text { Terend } \\
\text { ah }\end{array}$ & $\begin{array}{c}\text { Rat } \\
\text { a }- \\
\text { Rat } \\
\text { ar }\end{array}$ & $\begin{array}{c}\text { Devi } \\
\text { asi }\end{array}$ \\
\hline 1 & $\begin{array}{c}\text { Eksperi } \\
\text { men I }\end{array}$ & 100 & 65 & $\begin{array}{c}81, \\
88\end{array}$ & 6,8 \\
\hline 2 & $\begin{array}{c}\text { Eksperi } \\
\text { men II }\end{array}$ & 90 & 55 & $\begin{array}{c}73, \\
2\end{array}$ & 7,4 \\
\hline
\end{tabular}

Menentukan Kategori Rendah, Sedang, dan Tinggi Kelas Eksperimen Idan Kelas Eksperimen II

Análisis data penelitian untuk menentukan kategori tinggi, sedang, dan rendah kelas PBL dan kelas PjBL dengan cara membuat daftar distribusi frekuensi, menghitung nilai rata-rata (mean), standar deviasi dan menentukankategori tinggi, sedang, dan rendah.

Tabel 8 Persentase Hasil Belajar Siswa Ditinjau dari Persentase Nilai KategoriTinggi, Sedang dan Rendah

\begin{tabular}{cccccr}
\hline \multirow{2}{*}{ No } & Kategor & \multicolumn{2}{c}{ Kelas PBL } & \multicolumn{2}{c}{ Kelas PjBL } \\
\cline { 3 - 6 } & i & $\begin{array}{c}\text { Jumla } \\
\text { h } \\
\text { Siswa }\end{array}$ & $\begin{array}{c}\text { Jumla } \\
\mathbf{( \% )}\end{array}$ & $\begin{array}{c}\text { hiswa } \\
\text { Siswa }\end{array}$ \\
\hline 1 & Tinggi & 3 & $\begin{array}{c}10,7 \\
1 \%\end{array}$ & 1 & 3,8 \\
\hline 2 & Sedang & 24 & $\begin{array}{c}85,7 \\
2 \%\end{array}$ & 21 & 80 \\
\hline 3 & Rendah & 1 & $\begin{array}{c}3,57 \\
\%\end{array}$ & 4 & 15 \\
\hline
\end{tabular}

Berdasarkan dalam tabel 8 hasil perhitungan diperoleh persentase hasil belajar Fisika siswa ditinjau dari nilai kategori tinggi, sedang dan rendah.

\section{Uji Normalitas dan Uji Homogenitas}

Dari perhitungan uji normalitas data dengan menggunakan uji Chi Kuadrat diperoleh hasil bahwa data terdistribusi Normal. Selajutnya perhitungan homogenitas dilakukan dengan tujuan untuk mengetahui homogen atau tidaknya sampel penelitian. Uji homogenitas data dilakukan untuk membuktikan kesamaan varian kelompok untuk membentuk sampel. Uji homogenitas dalam penelitian ini dilakuakan dengan cara menggunakan uji F.

Kriteria uji homogenitas tolak $\mathrm{H}_{\mathrm{o}}$ jika $F_{\text {hit }} \geq F_{\text {tabel }}$ dengan $F_{\text {tabel }}=F_{1 / 2 \alpha}$ (V1v2). Dan terima $\mathrm{H}_{\mathrm{o}}$ untuk harga $\mathrm{F}_{\text {hit }}<$ $F_{\text {tabel. }}$ Serta besarnya $\alpha$ diambil $5 \% \mathrm{~V}_{1}=$ $\mathrm{n}_{1^{-}} 1$ dan $\mathrm{V}_{2}=\mathrm{n}_{2^{-}}$1(Sudjana, 2009). Nilai $F_{\text {hitung }}$ kemudian dibandingkan dengan nilai $F_{\text {tabel }}$ pada derajat kebebasan untuk pembilang $\mathrm{V}_{1}=\mathrm{n}_{2}-1=$ $28-1=27$ dan derajat kebebasan untuk penyebut $\mathrm{V}_{2}=\mathrm{n}_{1}-1=26-1=25$ dengan taraf signifikansi 5\%. $\mathrm{F}_{\text {tabel }}=\mathrm{F}_{0,05}(27-25)$ $=1,91$, dari perhitungan didapat $\mathrm{F}_{\text {tabel }}=$ 1,91. Berdasarkan nilai $F$ yang diperoleh dapat dilihat bahwa $\mathrm{F}_{\text {hit }}<\mathrm{F}_{\text {tabel }}=0,84<$ 1,91, maka Ha diterima. Dengan demikian dapat disimpulkan bahwa varian dalam penelitian ini adalah homogen.

Tabel 9 Uji Homogenitas

\begin{tabular}{ccc}
\hline $\mathbf{F}_{\text {tabel }}$ & $\mathbf{F}_{\text {hitung }}$ & Keputusan \\
\hline \multirow{2}{*}{1,91} & 0,84 & Homogen \\
\hline $3,8 \tilde{U}_{\text {ji Hipotesis }}$ &
\end{tabular}

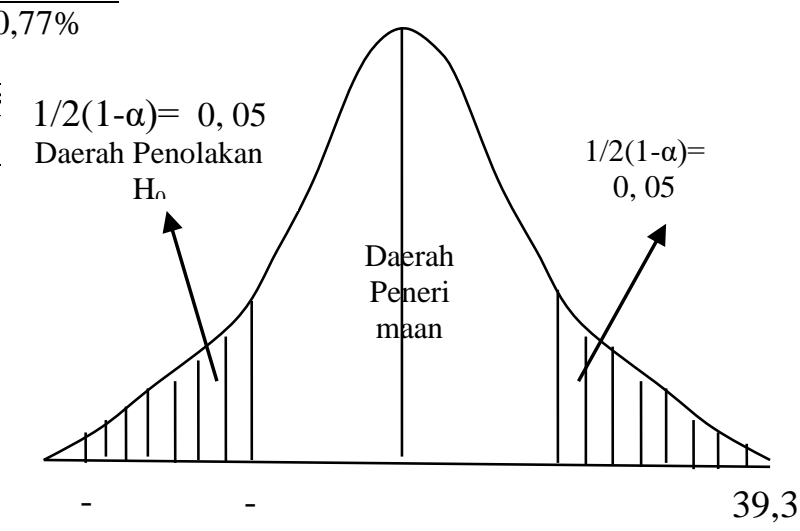

\section{Gambar 1 Kurva penerimaan dan penolakan hipotesis nol}

Nilai Z dari daftar normal baku dengan taraf signifikansi $5 \%$ yang memberikan $\mathrm{Z}_{0,475}$ adalah 1,96. Jadi 
kriteria pengujian yang dipakai adalah terima Ho jika $\mathrm{Z}_{\text {hit }}$ terletak antara $-1,96$ dan 1,96. Hasil perhitungan diperoleh nilai $Z_{\text {hit }}=39,3$ tidak terletak antara-1,96 dan 1,96, sehingga $\mathrm{H}_{0}$ di tolak dan $\mathrm{H}_{\mathrm{a}}$ diterima (Sudjana, 2009).

\section{PEMBAHASAN}

Pelaksanaan penelitian ini dilakukan pada tanggal 30 Mei 2018 06 Juni 2018 pada semester Genap Tahun Pembelajaran 2017/2018 pada peserta didik kelas VIII SMP Negeri 3 Belitang Madang Raya. Sedangkan untuk pemilihan kelas sebagai kelompol sampel dilakukan dengan cara memilih secara acak melalui undian. Kelas yang terpilih yaitu Kelas VIII.B sebagai kelas eksperimen I yang diberi perlakuan model pembelajaran PBL dan kelas VIII.C sebagai kelas eksperimen II yang diberi perlakuan model pembelajaran PjBL. Sebelum melaksanakan pembelajaran di kelas diperlukan alat dan bahan sebagai media pembelajaran serta perangkat pembelajaran yang meliputi Silabus Pembelajaran, Rencana Pelaksanaan Pembelajaran (RPP) kelas eksperimen I dan kelas eksperimen II, kartu soal, kisi-kisi soal, soal tes beserta kunci jawabannya.

Daryanto (2014) menjelaskan bahwa model pembelajaran PjBL adalah model pembelajaran yang menggunakan projek/kegiatan sebagai media. Peserta didik melakukan eksplorasi, penilaian, interprestasi, sintesis, dan informasi untuk menghasilkan berbagai bentuk hasil belajar. Menurut Warsono (2016) PjBL didefinisikan sebagai suatu pengajaran yang mencoba mengaitkan antara teknologi dengan masalah kehidupan sehari-hari yang akrab dengan siswa, atau dengan suatu proyek Sekolah. Pembelajaran ini menggunakan masalah sebagai langkah awal dalam menggumpulkan pengetahuan baru berdasarkan pengalamannya dalam beraktivitas secara nyata.
Menurut Daryanto (2014) beberapa karekteristik dari PjBL adalah: 1) peserta didik membuat keputusan tentang sebuah kerangka kerja, 2) adanya permasalahan atau tantangan yang diajukan kepada peserta didik, 3) peserta didik mendesain proses untuk menentukan solusi atas permasalahan atau tantangan yang diajukan, 4) peserta didik secara kolaboratif bertanggungjwab untuk mengakses dan mengolah informasi untuk memecahkan permasalahan, 5) proses evaluasi dijalankan secara kontinyu, 6) peserta didik secara berkala melakukan refleksi atas aktivitas yang sudah dijalankan, 7) produk akhir aktivitas belajar akan dievaluasi secara kualitatif, 8) situasi pembelajaran sangat toleran terhadap kesalahan dan perubahan.

Dalam meningkatkan hasil belajar siswa tidak hanya menggunakan model pembalajaran problem based learning (PBL), namun juga dapat diterapkan model pembelajaran yang lain, seprti temuan penelitian Gumay et all (2017) model pembelajaran two stay two stray dapat meningkatkan hasil belajar fisika. Kemudian menurut Lovisia (2017) hasil belajar siswa setelah diterapkan model make a match secara signifikan tuntas. Begitu juga menurut Ariani et all (2018) model pembelajaran student team achievement division (STAD) dapat menigkatkan hasil belajar siswa

\section{SIMPULAN}

Berdasarkan hasil analisis data dan pembahasan hasil penelitian yang dilakukan dapat disimpulkan bahwa terdapat perbedaan yang signifikan hasil belajar antara peserta didik yang pembelajarannya menggunakan model pembelajaran ProblemBasedLearening (PBL) dengan yang pembelelajarannya menggunakan model pembelajaran Project Based Learning (PjBL) pada Materi Getaran dan Gelombang di kelas 
VIII SMP Negeri 3 Belitang Madang Raya Tahun Pembelajaran 2017/2018.

DAFTAR PUSTAKA

Abdullah, R. (2017). Pembelajaran Sainstifik untuk Implementasi Kurikulum 2013. Jakarta: Bumi Aksara.

Ansori. (2008). Teori Taksonomi Bloom. Jakarta: Rineka Cipta.

Ariani, T., \& Agustini, D. (2018). Model Pembelajaran Student Team Achievement Division (STAD) dan Model Pembelajaran Teams Games Tournament (TGT): Dampak terhadap Hasil Belajar Fisika. Science and Physics Education Journal (SPEJ), 1(2), 65-77.

https://doi.org/https://doi.org/10.3 1539/spej.v1i2.271

Arikunto, S. (2010). Dasar-Dasar Evaluasi Pendidikan. Jakarta: Bumi Aksara.

Aunnurrahman. (2010). Belajar dan Pembelajaran. Bandung: Alfabeta

Daryanto. (2011). Media Pembelajaran. Bandung: Satu Nusa.

Daryanto. (2014). Media Pembelajaran. Bandung: Satu Nusa.

Depdiknas .(2003). Undang-undang RI No.20 tahun 2003.tentang sistem pendidikan nasional.

Gumay, O. (2017). Pengaruh Model Pembelajaran Kooperatif Tipe Two Stay Two Stray terhadap Hasil Belajar Fisika Siswa Kelas 8 SMP Negeri 3 Lubuklinggau. Science and Physics Education Journal (SPEJ), 1(1), 49-58. https://doi.org/https://doi.org/10.3 1539/spej.v1i1.102
Lovisia, E. (2017). Penerapan Model Make A Match pada Pembelajaran Fisika Kelas X Sma Negeri 2 Kota Lubuklinggau. Science and Physics Education Journal (SPEJ), $\quad 1(1), \quad 7-22$. https://doi.org/https://doi.org/10.3 1539/spej.v1i1.58

Rusman. (2014). Model-Model Pembelajaran. Jakarta: PT Raja Grafindo Persada.

Sudjana, N. (2009). Penilaian Hasil Proses Belajar Mengajar. Bandung: PT. Remaja Rosdakarya Sugiyono. (2010). Metode Penelitian Pendidikan Kuantitatif, Kualitatif, dan $R \& D$. Bandung: Alfabeta.

Warsono. (2016). Pembelajaran Aktif. Bandung: PT Remaja Rosdakarya. 